\title{
Arterial Lipid Metabolism in Relation, to Blood Glucose and Plasma Insulin in Rats with Streptozotocin-Induced Diabetes
}

\author{
R.W. Stout K.D. Buchanan, and J. Vallance-Owen \\ Department of Medicine, The Queen's University of Belfast \\ Received: July 6, 1972, accepted: August 24, 1972
}

\begin{abstract}
Summary. D-glucose-U. ${ }^{14} \mathrm{C}$ incorporation into arterial lipids in vitro was greater $(p<0.025)$ in control than in streptozotocin-treated $(65 \mathrm{mg} / \mathrm{kg})$ rats. A significant positive correlation between this effect and the plasma immunoreactive insulin levels was achieved, although there was no correlation with the blood glucose levels. It is suggested that the state of circulating insulin in the animal is important in modifying arterial lipid metabolism independent of changes in serum lipids.
\end{abstract}

Métabolisme des lipides des artéres en relation avec le glucose sanguin et l'insuline du plasma chez le rat rendu diabétique par la streptozotocine

Résumé. L'incorporation du D-glucose-U. ${ }^{14} \mathrm{C}$ dans les lipides des artères in vitro était plus grande $(p<0.025)$ chez les témoins que chez les rats traités à la streptozotocine $(65 \mathrm{mg} / \mathrm{kg})$. Une corrélation positive et significative entre cet effet et les taux de l'insuline immunoréactive du plasma a été réalisée, bien qu'il n'y ait aucune corrélation avec les taux du glucose sanguin. On suggère que le taux de l'insuline circulant dans l'animal est important par le fait qu'il modifie le métabolisme des lipides des artères indépendamment des changements dans les lipides du sérum.

Lipidmetabolismus der Arterien in Beziehung zu Blutzucker und Plasmainsulin bei der Ratte mit StreptozotozinDiabetes

Zusammenfassung. Die Inkorporation von D-U-14CGlucose in die Lipide der Arterien war in vitro bei den Kontrolltieren höher $(p<0,025)$ als bei den mit Streptozotozin $(65 \mathrm{mg} / \mathrm{kg}$ ) behandelten Ratten. Eine signifikant positive Korrelation konnte zwischen diesem Effekt und dem immunologisch reaktiven Plasmainsulin gefunden werden, obgleich keine Korrelation mit den Blutzuckerwerten bestand. Es wird angenommen, daß die Menge des im Tier zirkulierenden Insulins wesentlich ist, um den arteriellen Lipidmetabolismus unabhängig von den Veränderungen der Serumlipide zu beeinflussen.

Key words: Arterial, lipid, insulin, streptozotocin, immunoassay, atherosclerosis, glucose, diabetes.

\section{Indroduction}

A number of recent studies have shown that subjects with premature atherosclerotic vascular disease have abnormally high plasma insulin responses to both oral and intravenous glucose $[1-7]$.These studies have included subjects with disease of coronary $[1-5]$, cerebral [6] and peripheral arteries [7]. In addition, several well-known risk factors in atherosclerosis, including obesity [8] with and without glucose intolerance [9], and hypertriglyceridemia [10] are also associated with abnormally high levels of circulating insulin. It has been suggested that hyperinsulinism may have an important role in the pathogenesis of atherosclerosis [11].

It is now recognized that the artery is not merely an inert tube conducting fluid, but is a metabolically active tissue capable of synthesizing all the lipids found in the atherosclerotic plaque [12]. Evidence has been presented that insulin can stimulate the incorporation of both glucose and acetate into the lipids of the arterial wall $[13,14]$. However, this evidence was obtained from experiments using fairly large doses of exogenous insulin in vivo. Insulin has such widespread. effects on so many metabolic pathways throughout the body that it is impossible to be certain in the in vivo situation whether insulin exerted its effect directly on the arterial wall itself, or indirectly by way of changes in circulating precursors or in serum lipids. The experiments described here were designed to solve this problem, and to test the effect on arterial lipid metabolism of variations of insulin secretion within the physiological range.

\section{Material and Methods}

Wistar rats weighing about $150 \mathrm{~g}$ were weighed and injected intravenously with streptozotocin in a dose of $65 \mathrm{mg} / \mathrm{kg}$ (a dose known to produce diabetes) [15]. At the same time a similar group of rats were weighed and set aside as controls. Both groups of animals were fed commercial rat chow ad libitum and were not fasted prior to sacrifice. After two to four weeks the animals, both treated and control, were weighed and killed by decapitation. Blood was taken, and the aortas from the origin to the bifurcation were removed and carefully dissected free of adventitious tissue with the aid of a dissecting microscope.

The cleaned aortas were slit longitudinally and incubated for three hours in a Dubnoff shaker at $37^{\circ} \mathrm{C}$ at 100 oscillations per minute. The incubation medium con. sisted of $2.5 \mathrm{ml}$ Krebs Ringer bicarbonate buffer with $250 \mathrm{mg} \% \mathrm{D}$-Glucose and $0.1 \mu \mathrm{Ci} / \mathrm{ml}$ of D-glucose-U. ${ }^{14} \mathrm{C}$ (specific activity $3.0 \mathrm{mCi} / \mathrm{mM}$ ); the gas phase was $5 \%$ carbon dioxide in oxygen. 
At the end of the incubation the aortas were washed, and then refluxed for three hours in chloroform-methanol $(2: 1)$. The lipid solution was washed by the method of Folch et al. [16] which removes $99.9 \%$ of water-soluble contaminants, and made up to $2.5 \mathrm{ml}$ with chloroformmethanol. Samples of $0.5 \mathrm{ml}$ were placed in counting vials, the solvent evaporated, and the lipid redissolved in $10 \mathrm{ml}$ of toluene containing $0.4 \% 2.5$-diphenyl-oxazole and $0.04 \%$ 1-4-bis-(2-(5 phenyloxazoloyl)) benzene. Radioactivity was assayed in a Packard TriCarb scintillation spectrometer. A known fraction of the incubation medium was also assayed for radioactivity, using as scintillation fluid a 4:1 mixture of 1.4 dioxan and toluene, each containing $0.4 \% 2.5$-diphenyloxazole and $0.04 \% 1$-4-bis- $(2-(5$ phenyl-oxazoloyl)) benzene. The aortas were allowed to dry in air, and were then weighed.

In order to test for contamination of the aortas with fatty adventitious tissue, aortas from normal rats prepared as described above, were incubated under similar conditions in an incubation medium containing soluble insulin in a concentration $10000 \mu \mathrm{U} / \mathrm{ml}$. Control incubations were made in a medium containing no insulin. Extraction of lipids and estimation of radioactivity were as described above. When no effect of insulin on the aortas was found, epididymal fat pads from normal rats were incubated under identical conditions in insulin and control solutions, and the adequacy of the medium for showing an insulin effect on adipose tissue confirmed [17]. with $2.43 \pm 0.66 \mathrm{NM} / \mathrm{mg} / \mathrm{h}$ in the control solution $(t=$ $2.11 p<0.05$ ). As it has been shown that aortic adipose tissue is very sensitive to insulin [21], these results suggest that the aortas used in this experiment were free of adipose tissue. Histological evidence that the adventitious tissue was completely removed has already been presented [22].

The results of the experiment are shown in Table 1. Blood glucose was considerably higher in the streptozotocin treated rats than the controls, while the plasma insulin was approximately half that of the controls. Significantly more glucose was incorporated into the aortas of the control animals than the treated rats.

Correlation coefficients between the measurements were calculated. There was a significant positive correlation between the plasma insulin level and the glucose incorporation into aortic lipids (Figure). Plasma insulin also correlated with the weight change $(r=0.436 p<$ 0.005 ) which also correlated weakly but significantly with the glucose incorporation into aortic lipids $(r=$ $0.27 p<0.05$ ). There was a significant negative correlation between blood glucose and weight change $(r=$ $-0.638 p<0.0005)$. There was, however, no associa-

Table 1

\begin{tabular}{lccccc}
\hline Control & \multicolumn{5}{c}{ Streptozotocin } \\
\hline \multicolumn{7}{c}{ Blood glucose $(\mathrm{mg} / 100 \mathrm{ml})$} \\
$+4.67 \pm 0.90$ & $(15)$ & Weight change $(\mathrm{g} / 24 \mathrm{hs})$ & $543 \pm 25.76$ & $(21)$ & $p<0.0005$ \\
$29.08 \pm 6.16$ & $(13)$ & Plasma insulin $(\mu \mathrm{U} / \mathrm{ml})$ & $-1.27 \pm 0.48$ & $(26)$ & $p<0.0005$ \\
& & Glucose incorporated in & $14.00 \pm 3.30$ & $(25)$ & $p<0.025$ \\
$0.372 \pm 0.068(16)$ & aortic lipids $(\mathrm{NM} / \mathrm{mg} / \mathrm{h})$ & $0.210 \pm 0.026$ & $(26)$ & $p<0.025$ \\
\hline
\end{tabular}

a Mean \pm standard error of the mean. (Numbers in parentheses refer to number of observations).

The blood was taken into ice-cold tubes containing heparin and Trasylol $500 \mathrm{KIU} / \mathrm{ml}$ and the plasma immediately separated. Blood sugar was measured by a ferricyanide method on the autoanalyzer [18]. Plasma insulin was measured by radioimmunoassay using a chareoal method for separating free from bound insulin [19].

Student's " $t$ " test was used in the statistical analysis of the results, and correlation coefficients were calculated using the $\mathrm{r}$ to $\mathrm{z}$ transformation for small numbers [20].

\section{Results}

The aortas incubated in the insulin-containing solution incorporated $0.498 \pm 0.039 \mathrm{NM} / \mathrm{mg} / \mathrm{h}$ (mean \pm S.E.M.; $n=24$ ) glucose into lipid compared with $0.543 \pm 0.052 \mathrm{NM} / \mathrm{mg} / \mathrm{hr}(n=24)$ in the control solution $(t=0.71 p>0.20)$. Three fat pads incubated in the insulin-containing medium had an uptake of glucose into lipid of $20.78 \pm 8.68 \mathrm{NM} / \mathrm{mg} / \mathrm{h}$ compared tion between blood glucose and plasma insulin or glucose incorporation into aortic lipid.

Partial correlation coefficients between weight change and glucose incorporation into aortic lipid with plasma insulin held constant gave $r_{12 \cdot 3}=0.43$ which was not significant $(p>0.40)$. Similar calculations between weight change and plasma insulin with aortic lipid constant gave $r_{12 \cdot 3}=0.580(p<0.001)$ and between aortic lipid and insulin with weight constant gave $r_{12 \cdot 3}=0.532(p<0.0025)$. Thus the association between the weight change and the glucose incorporation into aortic lipids seems to be due to a common relationship to the plasma insulin level.

The results suggest that the incorporation of glucose into the lipids of the arterial wall is directly related to the circulating insulin level in the animal. The blood glucose level is an indication of disordered metabolism but is not itself responsible for the metabolic changes that occur. 


\section{Discussion}

These experiments show that the incorporation of glucose into the lipids of the arterial wall is depressed in streptozotocin treated animals. The insulin deficiency which results from the action of streptozotocin on the pancreatic beta cells leads to hyperglycemia. However, only the serum insulin level correlated significantly with the uptake of glucose into aortic lipids. Thus it seems that the state of circulating insulin in the animal is important in the regulation of arterial lipid metabolism. The results also suggest that the influence of insulin on arterial lipids occurs in the arterial which have not been properly cleaned, and the adventitious tissue itself both show a marked stimulation of lipid synthesis by insulin [21]. The fact that the aortas used in this experiment showed no insulin effect in vitro, together with the histological evidence that has already been presented [21] suggest that the vessels were free of fatty adventitious tissue. In addition, the pattern of lipid radioactivity found in arteries prepared in this way is quite different from that in the brown fat that is usually present in animal adventitious tissue [24].

The discrepancy between the results of studies of the effect of insulin on arterial lipid metabolism in vivo

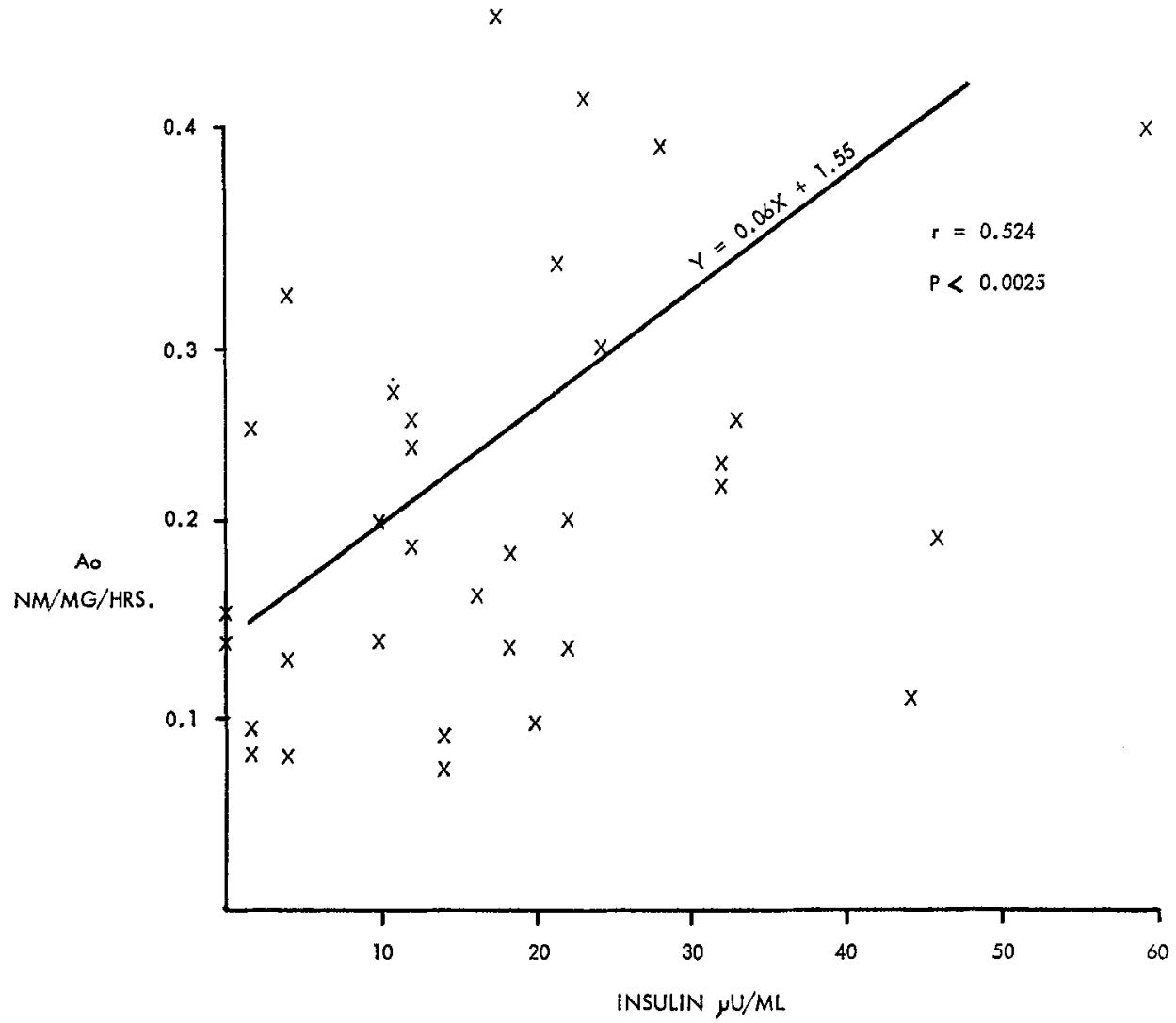

Fig. 1. Relation of glucose uptake into aortic lipids (Ao) in vitro with the plasma insulin concentration in vivo at the time the aorta was taken from the animal

wall itself, and not by way of changes in circulating precursors, or circulating lipids which infiltrate the artery.

Previous studies on the effect of insulin on arterial lipid metabolism have been criticized on the grounds that the arterial lipids may have been contaminated with adipose tissue which had not been adequately removed, and that the insulin effect was exerted on this tissue [23]. No effect on lipid metabolism occurs when arteries are incubated in insulin-containing solutions in vitro if all the adventitious tissue has been meticulously removed from the specimens [21]; arteries and in vitro remains unresolved. A similar situation has been reported in that insulin added in vitro has no effect on the depressed glucose uptake into vessels of alloxanized animals [25]. Pretreatment of the animals with insulin for at least eighteen hours is required to return arterial metabolism towards normal. However, insulin does enhance the incorporation of glucose into lipid in arterial intimal cells grown in culture [26].

The arterial wall contains a hormone sensitive lipase which is inhibited by insulin [27]. The experiments reported here suggest that arterial lipogenesis may also be regulated by insulin. Thus hyperinsulinism 
may promote lipid deposition in the artery both by enhancing lipogenesis and by inhibiting lipolysis, an action similar to its activity on adipose tissue [28]. Insulin mediated lipid synthesis in the arterial wall may thus be one way in which insulin and atheroma are causally linked [11].

Acknowledgments. This work was supported by grants from the British Diabetic Association and the Medical Research Council.

\section{References}

1. Peters, N., Hales, C. N. : Plasma insulin concentrations after myocardial infarction. Lancet 1965 I, 11441145 .

2. Nikkila, E.A., Miettinen, T.A., Vesenne, M.R., Pelkonen, R.: Plasma insulin in coronary heart disease. Lancet 1965 II, 508-511.

3. Christiansen, I., Deckert, T., Kjerulf, K., Mitgaard, K., Warning, H. : Glucose tolerance, plasma lipids and serum insulin in patients with ischaemic heart disease. Acta med. scand. 184, 283-287 (1968).

4. Tzagournis, M., Chiles, R., Ryan, J.M., Skillman, T. G.: Interrelationships of hyperinsulinism and hypertriglyceridemia in young patients with coronary heart disease. Circulation 38, $1156-1163$ (1968).

5. Kashyap, M. L., Magill, F., Rojas, L., Hoffman, M. M.: Insulin and non-esterified fatty acid metabolism in asymptomatic diabetics and atherosclerotic subjects. Canad. med. Assoc. J. 102, $1165-1169$ (1970).

6. Gertler, M.M., Leetma, H.E., Saluste, E., Welch, J.J., Rusk, H.A., Covalt, D.A., Rosenberger, J.: Carbohydrate, insulin and lipid interrelationship in ischaemic vascular disease. Geriatries $25,134-148$ (1970).

7. Sloan, J.S., Mackay, J.S., Sheridan, B.: Glucose tolerance and insulin response in atherosclerosis. Brit. med. J. 4, 586- 588 (1970).

8. Bagdade, J.D., Bierman, E.L., Porte, D., Jr.: Significance of basal insulin levels in the evaluation of the insulin response to glucose in diabetic and non-diabetic subjects. J. clin. Invest. 46, 1549-1557 (1967).

9. Porte, D., Jr., Bagdade, J.D.: Human insulin secretion: an integrated approach. Ann. Rev. Med. 21, $219-240(1970)$.

10. Bagdade, J.D., Bierman, E.L., Porte, D., Jr.: The influence of obesity on the relationship between insulin and triglyceride levels in endogenous hypertriglyceridemia. Diabetes 20, 664-672 (1971).

11. Stout, R. W., Vallance-Owen, J.: Insulin and atheroma. Lancet 1969 I, 1078-1080.

12. Newman, H.A.I., McCandless, E.L., Zilversmit, D. B. : The synthesis of $14 \mathrm{C}$-lipids in rabbit atheromatous lesions. J. biol. Chem. 236, 1264-1268 (1961).
13. Stout, R.W.: Insulin stimulated lipogenesis in the arterial wall in relation to diabetes and athoroma. Lancet 1968 II, $702-703$.

14. Stout, R.W.: Insulin stimulation of cholesterol synthesis by arterial tissue. Lancet $1969 \mathrm{II}, 467-468$.

15. Junod. A., Lambert, A.E., Stauffacher, W., Renold, A.E.: Diabetogenic action of streptozotocin: relationship of dose to metabolic response. J. clin. Invest. $48,2129-2139$ (1969).

16. Folch, J., Lees, M., Stanley, G.H. S.: A simple method for the isolation and purification of total lipids from animal tissues. J. biol. Chem. 226, 497-509 (1957).

17. Winegrad, A.I., Renold, A. E. : Studies on rat adipose tissue in vitro. I. Effects of insulin on the metabolism of glucose, pyruvate and acetate. J. biol. Chem. 233, $267-271$ (1958).

18. Hoffman, W.S.: A rapid photoelectric method for the determination of glucose in blood and urine. $\mathrm{J}$. biol. Chem. 120, 51-53 (1937).

19. Buchanan, K.D., MeCarroll, A.M.: Comparison of methods of separation of free from bound hormone in the radioimmunoassay of insulin and glucagon. In: Radioimmunoassay Methods. Edinburgh: Livingstone 1971.

20. Fisher, R.A.: Statistical methods for research workers. Edinburgh: Oliver and Boyd 1958.

21. Urrutia, G., Beavan, D.W., Cahill, C.F.: Metabolism of glucose-U-C14 in rat aorta in vitro. Metabolism 11, $530-534$ (1962).

22. Stout, R.W.: The effect of insulin on the incorporation of $\left(\mathrm{I}^{14} \mathrm{C}\right)$ sodium acetate into the lipids of the rat aorta. Diabotologia 7, 367-372 (1971).

23. Vost, A., Hollenberg, C.H.: Insulin and atherosclerosis. Lancet 1969 II, $218-219$.

24. Stout, R. W.: Insulin and atheroselerosis. Lancet 1969 II, $327-328$.

25. Mulcahy, P.D., Winegrad, A.I. : Effects of insulin and alloxan diabetes on glucose metabolism in rabbit aortic tissue, Amer. J. Physiol. 203, 1038-1042 (1962).

26. Mahler, R., Parkes, A.B.: Fat synthesis in cultures of cells of arterial intima. Europ. J. Clin. Invest. I, 137 (1970).

27. Mahler, R.: Insulin action on arterial tissue in relation to diabetes and atheroma. Duncan, L.J.P. (Ed.): Diabotes Mellitus. Edinburgh: Edinburgh University Press 1966.

28. Renold, A.E., Crofford, O.B., Stauffacher, W., Jeanrenaud, B. : Hormonal control of adipose tissue metab olism, with special reference to the effects of insulin. Diabetologia 1, 4-12 (1965).

Prof. J. Vallance-Owen

The Queen's University of Belfast

Dept. of Medicine

Grosvenor Road

Belfast BT 126 BJ

Ireland 